\title{
PITANJA KOJA NASTAVNICI ENGLESKOG KAO STRANOG JEZIKA POSTAVLJAJU U NASTAVI
}

\author{
Kristina Vuleta, Anna Martinović \\ Odjel za anglistiku, Sveučilište u Zadru, Hrvatska \\ kvuleta@unizd.hr; amartino@unizd.hr
}

Primljeno: 20. 12. 2018.

\begin{abstract}
Nastavnici postavljanjem pitanja doprinose procesu učenja stranog jezika i razvoju mišljenja višeg reda kod učenika. Pitanja su značajna za pokretanje interakcije u učionicama stranih jezika. Cilj ovog istraživanja bio je dobiti uvid u vrste pitanja koje nastavnici koriste u poučavanju engleskog kao stranog jezika (engl. EFL). Metoda prikupljanja podataka uključivala je promatranje nastave koje se često koristi u istraživanjima u učionicama stranih jezika. Rezultati su pokazali da se u osnovnim i srednjim školama češće postavljaju pitanja nižeg reda od pitanja višeg reda, dok su složenija pitanja i setovi pitanja i odgovora pokazali veću učestalost pitanja višeg reda. Nadalje, složenost odgovora učenika ovisila je o vrsti pitanja koju je nastavnik postavio. Analiza je također pokazala da, usprkos tome što je bilo više pitanja koja su poticala na razmišljanje $i$ samoizražavanje u srednjoj školi nego u osnovnoj školi, veliki broj prikupljenih pitanja nižeg reda ipak pokazuje potrebu za većom upotrebom pitanja višeg reda.
\end{abstract}

Ključne riječi: pitanja koja nastavnici postavljaju, engleski kao strani jezik (engl. EFL), provjerna pitanja, stvarna pitanja

\section{Uvod}

Jedan od ključnih ciljeva obrazovnih stručnjaka je unaprjeđenje procesa učenja. $U$ današnjem globaliziranom svijetu znanje je postalo neophodna roba koju svaki pojedinac treba posjedovati. Tehnološke promjene povećale su potrebu ne samo za osnovnim znanjem nego i za kritičkim razmišljanjem te vještinama rješavanja problema. Pitanja koja nastavnici postavljaju smatraju se najučinkovitijim načinom pro- 
vjere znanja učenika u razredu, kao i poboljšanja sposobnosti mišljenja višeg reda (Walsh i Sattes, 2014). S obzirom na to da trenutna obrazovna reforma u Hrvatskoj (»Škola za život«) za cilj ima razviti kritičko mišljenje učenika, nastavnike bi valjalo osvijestiti o ulozi uporabe pitanja koja doprinose razvoju te vještine (Priprema, praćenje $i$ evaluacija eksperimentalnog programa cjelovite kurikularne reforme »Škola za život«, 2019). Unutar područja učenja drugog ili inog jezika pojavom Komunikacijskog pristupa (KP, engl. Communicative Language Teaching - CLT) dolazi do poticanja stvarne komunikacije. Takav način poučavanja stavlja naglasak na interakciju učenika i nastavnika u učionicama stranih jezika. Štoviše, pitanja koja nastavnici postavljaju osnovni su element procesa učenja jezika i jedna od najučestalijih metoda uključivanja učenika u interakciju. Ur (2012) kategorizira pitanja koja nastavnici postavljaju na temelju odgovora koje pitanje zahtijeva od učenika, a to su pitanja nižeg i pitanja višeg reda. Kako bi se utvrdio način na koji nastavnici postavljaju pitanja u nastavi engleskog jezika, cilj ovog rada bio je istražiti koje vrste pitanja nastavnici postavljaju, koliko često koriste određeni tip pitanja, koja je svrha postavljenih pitanja i postoji li razlika u pitanjima koja nastavnici postavljaju u osnovnim i srednjim školama.

\section{Teorijska pozadina}

\subsection{Komunikacijski pristup poučavanju jezika}

Tijekom godina nastali su različiti pristupi i metode u području poučavanja jezika. Među novijim i najutjecajnijim je i komunikacijski pristup poučavanju jezika (KP), koji je razvijen krajem 70-ih i početkom 80-ih godina 20. stoljeća. Polazna pretpostavka KP je da jezik služi za komunikaciju i zbog toga se u učionici treba poticati stvarna komunikacija. Glavni cilj KP je omogućiti učenicima postizanje komunikacijske kompetencije uključujući gramatičku kompetenciju, kompetenciju u jezičnom diskursu, sociolingvističku kompetenciju te stratešku kompetenciju u ciljnom jeziku. Uz spomenute kompetencije, važno je razvijati i jezične vještine, primjerice, vještinu slušanja, govorenja, čitanja i pisanja, kroz različite aktivnosti (Harmer, 2007). Štoviše, naglasak je na funkcionalnosti jezika u smislenom kontekstu zajedno s jezičnim oblikom (Brown i Lee, 2015). Tečnost i točnost smatraju se 
»komplementarnim načelima na kojima se temelje komunikacijske tehnike « (Brown, 2007, 46), što znači da će u nekim slučajevima učenici biti usredotočeni na tečnost i uporabu jezika, a u drugim slučajevima na točnost; drugim riječima, dužnost je ravnomjerno razvijati oba aspekta komunikacije. U centru pažnje su potrebe učenika, a naglašava se i suradničko učenje. Nastavnici postaju voditelji i 'uslužni djelatnici', kao i osiguravatelji sigurne okoline u kojoj učenici postaju svjesni vlastitih stilova učenja i prikladnih strategija učenja koje pomažu u razvoju autonomije.

\subsection{Interaktivno učenje jezika}

Žarište novih pristupa poučavanju drugog i stranog jezika je stvarna komunikacija. Upravo zbog toga interakcija je zadobila vrlo važnu ulogu u učenju jezika. Prema Brownu (2007, 212), interakcija je »suradnička razmjena misli, osjećaja i ideja između dvoje ili više ljudi, koja rezultira recipročnim učinkom na sve sudionike«, i svaki bi nastavnik te pojmove trebao uzeti u obzir. Nadalje, autor opisuje nekoliko obilježja interaktivne nastave poput rada u paru i grupnog rada, aktivnosti koje uključuju autentičnu komunikaciju i korištenje jezika u stvarnim kontekstima, kao i vježbu suradnje i pregovaranja u razgovoru. U interaktivnoj nastavi nastavnik je taj koji započinje interakciju i pruža poticaj učenicima. Nastavnici kao pokretači interakcije moraju obratiti pažnju na način na koji započinju interakciju, koje vrste pitanja koriste i jesu li informacije koje daju značajne učenicima.

KP i metoda interaktivnog poučavanja jezika u skladu su s rezultatima istraživanja o usvajanju drugog jezika. Long (1996) svojom Hipotezom o interakciji (engl. Interaction hypothesis) tvrdi da je utjecaj društvene interakcije na proces ovladavanja stranim jezikom vidljiv $u$ preinakama kojima sugovornici pribjegavaju kako bi interakciju učinili uspješnom, odnosno kako bi se međusobno razumjeli. Nadalje, interakcija uključuje pregovaranje o značenju poruke koje može dovesti do jezičnog unosa (Long, 1996) (engl. language input), kao i jezičnog ostvaraja (Swain, 1985; 1995) (engl. language output) koji ima ključnu ulogu u usvajanju jezika. Istraživanja interakcije u nastavi usmjerila su se na različite dijelove interakcije, uključujući govorne razmjene među sudionicima, komunikacijske strategije, kao i govor nastavnika i učenika (Vrhovac, 2001). Prema Ur (2012), interakcija u jezičnim učionicama uključuje različite obrasce interakcije poput govora nastavnika, 
zbornog odgovaranja, interakcije cijelog razreda, suradnje, ispitivanja nastavnika, grupnog rada i rada u paru, samostalnog rada i kombinacije obrazaca. Postavljanje pitanja je među najvažnijim metodama koje nastavnici koriste kako bi započeli i održali interakciju. Vrhovac (2001, 84-85) ističe važnost pitanja u interakciji tvrdeći da su »pitanje i odgovor osnovni dijelovi strukture dijaloga«, ponavljajući kako višestruka uloga pitanja u nastavi uključuje i to da je »pitanje oduvijek bilo i ostaje najčešći oblik poticanja na razmišljanje, koristi se kod traženja rješenja problema, sredstvo je koje potiče na zaključivanje« (Vrhovac, 2001, 84-85).

\subsection{Razredni diskurs}

Interakcija u razredu počiva na nastavnicima jer su oni ti koji ju započinju postavljanjem pitanja (Brown, 2007; Chaudron, 1988). Walsh (2011) opisuje najučestaliji oblik interakcije u nastavi, tj. razredni diskurs, koji se sastoji od tri dijela: Inicijacija - Odgovor - Povratna informacija (engl. Initiation - Response - Feedback; IRF) ili Inicijacija - Odgovor - Evaluacija (engl. Initiation - Response-Evaluation; IRE). Nastavnik započinje razgovor, obično s pitanjem, učenik odgovara i nastavnik daje povratnu informaciju koja može biti procjena, ispravak ili komentar. Sinclair i Coulthard (1975) prvi su predstavili ovu strukturu što je uvelike utjecalo na razumijevanje interakcije između nastavnika i učenika. Walsh $(2018,18)$ navodi nekoliko prednosti korištenja IRF strukture $\mathrm{u}$ istraživanju interakcije u nastavi:

- omogućuje nam shvatiti posebnu prirodu interakcije u nastavi;

- omogućuje nam shvatiti zašto nastavnici govore puno više od učenika: za svaku jednu izjavu učenika (engl. $R$ ), nastavnici obično pruže dvije (engl. $I, F$ );

- pokazuje nam kako interakcija u razredu, ako se previše koristi, može postati mehanička, pa čak i monotona. Nastavnici ovoga moraju biti svjesni.

Rezultati istraživanja govora nastavnika inog jezika u skladu su s rezultatima istraživanja materinskog jezika u smislu da ukazuju na činjenicu da dvije trećine sveukupnog vremena pripadaju govoru nastavnika (Chaudron, 1988; Allwright i Baily, 1991). Nadalje, mnoga su istraživanja potvrdila da nastavnici postavljaju puno pitanja. Long i Sato (1984, u: Ellis, 2008) su primjerice otkrili da su nastavnici po- 
stavili 938 pitanja tijekom šest sati nastave engleskog kao inog jezika na osnovnoj razini. Također su otkrili da su nastavnici engleskog kao drugog stranog jezika najčešće postavljali pitanja zatvorenog tipa i provjerna pitanja (engl. display questions), pitanja koja traže informaciju već poznatu učenicima, u usporedbi s referentnim pitanjima (engl. referential questions) koja traže opću informaciju. Long i Sato (1983) smatraju da smanjena uporaba referentnih pitanja može upućivati na nedostatak smislene komunikacije u učionici stranih jezika. Takav tip komunikacije smatra se ključnim dijelom KP. Brock (1986) je otkrila da su odgovori učenika na referentna pitanja znatno dulji od odgovora na provjerna pitanja, što uvelike potiče govor učenika. Štoviše, Hattie (2008) tvrdi da pitanja nižeg reda mogu iznuditi samo odgovore nižeg reda i da samo pitanja višeg reda mogu dovesti do značajne komunikacije.

U hrvatskom kontekstu istraživanjem interakcije u razredu bavile su se Vrhovac (2001) i Čurković Kalebić (2012). Vrhovac (2001) tvrdi da postoje velike razlike između razrednog i naturalističkog diskursa. Naime, nastavnici u razredu su puno više skloni postavljanju provjernih pitanja u usporedbi s referentnim pitanjima kod povjeravanja naučenog. Međutim, autorica smatra da bi »najbolje i najkorisnije za razvoj učenikove komunikacijske kompetencije bilo kada bi nastavnik kombinirao jednu i drugu vrstu pitanja« (Vrhovac 2001, 87). Čurković Kalebić (1993) došla je do rezultata da su nastavnici učestalije koristili pitanja zatvorenog tipa od pitanja otvorenog tipa, iz čega proizlazi da se koristio manje kompleksan jezik. Ćurković Kalebić (2012) svojim je istraživanjem otkrila da su se pitanja učenika odnosila na nastavne aktivnosti, dok su učenici viših razreda osnovnih škola postavljali pitanja vezana za učenje jezika. Nadalje, nastavnici bi češće izravno odgovarali na pitanja nego što bi postavili protupitanje. Ovo saznanje autoricu je navelo na zaključak da se ova metoda rijetko koristi kod nastavnika u Hrvatskoj na razini osnovne škole.

Nastavnici postavljaju pitanja iz brojnih razloga, a ispitivanje može imati različite funkcije u razredu. Ur (2012, 228-229) zaključuje da nastavnici postavljaju pitanja kako bi se:

- pružio model govora ili razmišljanja;

- nešto doznalo od učenika;

- provjerilo ili ispitalo razumijevanje, znanje ili vještina; 
- učenike naviknulo na aktivno učenje;

- usmjerila pažnja ili napravio uvod u temu koja će se proučavati;

- informiralo razred kroz odgovore učenika, a ne kroz podražaj nastavnika;

- slabijim učenicima pružila prilika za sudjelovanjem;

- potaknulo razmišljanje (logičko, kritičko i kreativno);

- dublje ušlo u probleme;

- učenici osobno povezali s problemom;

- učenici pregledali i vježbali što su već učili;

- potaknulo samoizražavanje;

- učenicima dalo do znanja da nastavnika zaista zanima njihovo mišljenje.

Good i Brophy (2008) tvrde da se pitanja ne koriste samo da bi se ispitao sadržaj nego i da bi se sadržaj učinio značajnijim. Pitanja bi trebala učenike poticati na razmišljanje o sadržaju, kao i na povezivanje s onim što su prije učili, istovremeno pokušavajući primijeniti naučeno u novim situacijama. Koristeći ovaj pristup učenici mogu analizirati sadržaj i postaju svjesni važnih informacija sadržaja, a time imaju mogućnost ponoviti ih na svoj način. Pitanja imaju funkciju izgradnje ideja kao temelj za izgradnju strukturiranog znanja.

Sve navedene svrhe i funkcije pitanja zahtijevaju različite vrste pitanja, a brojni autori ponudili su različite klasifikacije. Clegg (1987, u: Wilen, 1987) ukratko opisuje klasifikacije počevši s Bloomovom taksonomijom (1956) obrazovnih ciljeva koja je služila kao sredstvo boljeg razumijevanja ciljeva i aktivnosti poučavanja. Kasnije je Sanders (1966) nadopunio Bloomovu taksonomiju (1956) te je opisao i kategorizirao brojne vrste pitanja koja nastavnici postavljaju, stvarajući istovremeno temelj za istraživanja usmjerena na kognitivne razine pitanja. Guilford (1956) je predstavio svoj model i utvrdio konvergentni i divergentni proces razmišljanja koji su povezani s kreativnošću. Njegov model koristili su Gallagher i Aschner (1963) da bi opisali pet skupina pitanja koja se pojavljuju u razredu: kognitivno-memorijska, konvergentna, divergentna, evaluacijska i rutinska. Konvergentna se odnose na ona pitanja koja zahtijevaju jedan točan odgovor bez mogućnosti daljnjeg razvoja ideje, dok divergentna zahtijevaju veliki raspon mogućih odgovora, stoga je naglasak na kreativnosti. 
Long i Sato (1984) prikazali su klasifikaciju pitanja koja nastavnici postavljaju, a koja se temelji na promatranju nastave jezika te uključuje provjerna i referentna pitanja. Ur (2012) nudi klasifikaciju koja se temelji na četiri kriterija: autentičnost komunikacije, duljina očekivanog odgovora, broj očekivanih odgovora i potrebna razina razmišljanja. Autentičnost komunikacije vidljiva je kroz stvarna pitanja (engl. genuine questions) i provjerna pitanja (engl. display questions). Stvarna pitanja potiču učenike na stvarnu komunikaciju, s obzirom da su vjerodostojna i nastavnik ne zna odgovor. Provjerna pitanja pokazuju ili prikazuju učenikovo znanje, traže određene informacije i obično se koriste za vježbu, a nastavnik već posjeduje odgovor. Drugi kriterij odnosi se na duljinu očekivanog odgovora, a postoje pitanja koja zahtijevaju kratke odgovore i pitanja koja zahtijevaju dulje odgovore. Kratki odgovori mogu biti riječ, fraza ili kratka rečenica, dok dugi odgovori mogu biti duga rečenica ili više rečenica. Treći kriterij odnosi se na broj očekivanih odgovora pa postoje pitanja otvorenog i zatvorenog tipa. Pitanja otvorenog tipa obično imaju više mogućih odgovora, kratkih i dugih, s obzirom da ne postoji jedan točan odgovor. Takva su pitanja korisna za poticanje učenika na aktivnost i razvoj tečnosti. Pitanja zatvorenog tipa obično imaju kratke odgovore, a postavljaju se kako bi se provjerilo znanje ili razumijevanje. Zadnji kriterij je potrebna razina razmišljanja, koja je usko vezana za već spomenute kriterije jer vrste pitanja u ostalim kriterijima odgovaraju ili mišljenju nižeg reda ili mišljenju višeg reda, iako to nije pravilo. Pitanja nižeg reda obično su provjerna pitanja, pitanja zatvorenog tipa i pitanja koja imaju kratke odgovore. Odnose se na pružanje jednostavnih informacija ili činjenica bez kritičkog pristupa. Suprotno tomu, pitanja višeg reda uključuju stvarna pitanja, pitanja otvorenog tipa i pitanja koja imaju dulje odgovore, stoga uključuju »dublje razumijevanje, primjenu, analizu, kritiku, procjenu ili kreativnost « (Ur, 2012, 230). Ur predlaže nastavnicima da koriste obje vrste pitanja. Međutim, isto tako tvrdi da nastavnici zanemaruju pitanja višeg reda zbog oblikovanja pitanja u planiranju nastavnog sata, što oduzima puno vremena, a može i izazvati poteškoće u praćenju i ispravljanju odgovora.

Nastavnici moraju pažljivo planirati sat kako bi postavljanje pitanja bilo što učinkovitije. Pritom je važno obratiti pozornost na više čimbenika. Primjerice, moraju razmišljati o nastavnim ciljevima koje žele postići i kako ih mogu realizirati kroz postavljanje pitanja. Vrste 
pitanja su vrlo važne i moraju odgovarati ciljevima, kao i potrebama učenika. Stoga nastavnici moraju unaprijed odlučiti koja je svrha svakog postavljenog pitanja.

\section{Istraživanje}

\subsection{Ciljevi}

Uzevši u obzir da pitanja koja koriste nastavnici mogu pomoći u razvoju mišljenja višeg reda učenika, drugim riječima u razvoju vještine kritičkog razmišljanja, glavni cilj ovog istraživanja bio je ponuditi deskriptivnu analizu vrsta pitanja koja nastavnici koriste u poučavanju inog jezika i njihove učestalosti. Nadalje, uzelo se u obzir i odgovore učenika kako bi se provjerilo potiču li pitanja koja koriste nastavnici razmišljanje višeg reda. Naposljetku, raspravljalo se i o razlikama među pitanjima koja postavljaju nastavnici u osnovnim i srednjim školama i odgovora učenika različitih dobnih skupina. Ovim istraživanjem pokušat će se dati odgovor na sljedeća pitanja:

1) Koje vrste pitanja nastavnici postavljaju u jezičnim učionicama?

2) Koje vrste pitanja se najčešće postavljaju?

3) Postoji li povezanost između vrsta pitanja i kompleksnosti odgovora učenika?

4) Koja je svrha postavljanja pitanja?

5) Koje su razlike u postavljanju pitanja nastavnika u osnovnim i srednjim školama?

\subsection{Metode}

\subsubsection{Uzorak istraživanja}

Istraživanje je provedeno u Zadru krajem prvog polugodišta i početkom drugog polugodišta školske godine. Sudionici su nastavnici i učenici triju osnovnih škola: OŠ Petar Preradović, OŠ Šime Budinić i OŠ Bartul Kašić te nastavnici i učenici triju srednjih škola: Klasična gimnazija Ivana Pavla II., Gimnazija Vladimira Nazora i Medicinska škola Ante Kuzmanića. Iz svake škole sudjelovao je po jedan nastavnik engleskog jezika, tj. ukupno šest nastavnika, te 210 učenika iz šest 
škola: učenici prvog, šestog i sedmog razreda u osnovnim školama i učenici prvog, drugog i četvrtog razreda u srednjim školama.

\subsubsection{Instrumenti istraživanja}

U svrhu ovog istraživanja podatci su prikupljeni tijekom 12 nastavnih sati korištenjem metode promatranja nastave i vođenja bilješki. Nunan i Bailey $(2009,258)$ navode da se prikupljanje podataka tijekom promatranja nastave može obavljati elektronski (video-zapisi, audiozapisi itd.) i/ili ručno (vođenje bilješki, promatranje prema predlošku). Razlog zbog kojeg se nije odabralo audio-snimanje je taj što se neki od nastavnika nisu složili s tom metodom. S obzirom na ispravnost metode vođenja bilješki, koju su potvrdili Nunan i Bailey (2009) i Mackey i Gass (2005), autorice su je odlučile primijeniti kako bi prikupile podatke. U svakoj školi obavljena su po dva sata promatranja nastave u različitim razrednim odjelima. U osnovnim školama prikupljeno je 55 pitanja te 11 setova pitanja i odgovora, a u srednjim školama prikupljena su 52 pitanja i 11 setova pitanja i odgovora. Kako bi se utvrdile vrste pitanja koja nastavnici postavljaju, pitanja su se analizirala pomoću kriterija svrstavanja pitanja koja je ponudila Ur (2012), a temelji se na podjeli pitanja na provjerna i stvarna pitanja, pitanja otvorenog i zatvorenog tipa, pitanja koja zahtijevaju kratke ili duge odgovore te pitanja nižeg i višeg reda. Kako bi se ustanovila povezanost vrsta pitanja i kompleksnosti odgovora učenika koristio se zadatak koji je predložila Wajnryb (1992/2012, 48). Naposljetku, na temelju prikupljenih i analiziranih podataka izneseni su zaključci vezani za razlike u postavljanju pitanja nastavnika u osnovnim i srednjim školama.

\subsubsection{Postupak $i$ analiza podataka}

Nastavnici su bili upoznati s ciljevima istraživanja, procedurama i metodama prikupljanja podataka. Nakon pristanka škola i nastavni$\mathrm{ka}$, istraživači su posjetili tri osnovne i tri srednje škole. Prema prethodnom iskustvu u promatranju nastave i prikupljanju pitanja koja nastavnici postavljaju, bila su potrebna najmanje dva školska sata promatranja kako bi se prikupila dovoljna količina podataka, što znači da je obavljeno 12 sati promatranja nastave. Prikupljala su se pitanja koja su postavljali isključivo nastavnici, a učenici bi odgovarali. Tijekom svakog sata bilježena su pitanja koja je postavljao nastavnik i učenikov odgovor (Incijacija - Odgovor) te setovi pitanja koja postavi nastavnik 
i odgovora koje ponudi učenik. Setovi pitanja temeljeni su na obliku interakcije Inicijacija - Odgovor - Povratna informacija (engl. IRF) koji se smatrao cjelovitim govornim činom. Broj postavljenih pitanja razlikovao se od sata do sata ovisno o temama i nastavnim cjelinama. Podatci prikupljeni i u osnovnim i u srednjim školama kategorizirani su prema klasifikaciji pitanja koju je predložila Ur (2012). Pitanja su prvo klasificirana prema autentičnosti komunikacije, a uključuju stvarna i provjerna pitanja. Druga dva kriterija su duljina odgovora i broj očekivanih odgovora. Također, pitanja su bila klasificirana u dvije velike grupe: pitanja koja zahtijevaju mišljenje nižeg reda i pitanja koja zahtijevaju mišljenje višeg reda. Pitanja nižeg reda uključuju provjerna pitanja, pitanja zatvorenog tipa i pitanja koja zahtijevaju kratke odgovore, dok pitanja višeg reda uključuju stvarna pitanja, pitanja otvorenog tipa i pitanja koja zahtijevaju dulje odgovore.

U drugom dijelu analize rangirano je 11 setova pitanja i odgovora prema kompleksnosti odgovora učenika prema Wajnryb (2012). Setovi su kategorizirani na temelju duljine odgovora i složenosti jezika. Također je analizirana svrha postavljanja pitanja te ih se kategoriziralo prema klasifikaciji funkcija pitanja koja nastavnici postavljaju, a koju je predložila Ur (2012). Naposljetku, na temelju prikupljenih podataka opisane su razlike u vrstama pitanja koja nastavnici postavljaju u osnovnim i srednjim školama.

\section{Rezultati}

U ovom dijelu predstavljeni su rezultati analize pitanja nastavnika i odgovora učenika kao i setova pitanja i odgovora u osnovnim i srednjim školama u Hrvatskoj.

\subsection{Rezultati analize pitanja u osnovnim školama}

Prvi cilj bio je utvrditi koje vrste pitanja koriste nastavnici u osnovnim školama. Na temelju analize 55 pitanja utvrđeno je da nastavnici u osnovnim školama koriste različite vrste pitanja. Koristeći se kategorizacijom koju je predstavila Ur (2012), u kategoriji autentičnosti komunikacije postavljeno je ukupno $12(22 \%)$ stvarnih pitanja i 43 (78 $\%)$ provjerna pitanja. U kategoriji duljine odgovora rezultati pokazuju da 38 (69 \%) pitanja zahtijeva kratke odgovore, a 17 (31\%) pitanja zahtijeva dulje odgovore. Štoviše, ukupno je postavljeno 37 (67 \%) pi- 
tanja zatvorenog tipa te 18 (33\%) pitanja otvorenog tipa. Rezultati su prikazani u Grafikonu 1.

Grafikon 1. Vrste pitanja koje se koriste u osnovnim školama

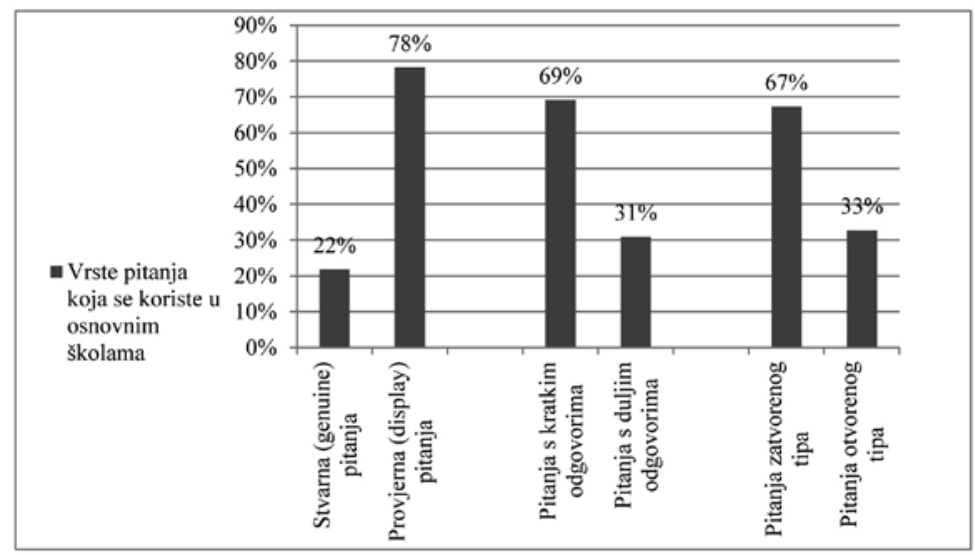

Kako bi se utvrdilo koje se vrste pitanja najčešće postavljaju, pitanja su bila kategorizirana kao pitanja nižeg i pitanja višeg reda. U kategoriji pitanja nižeg reda 43 pitanja bila su provjerna pitanja, 38 je zahtijevalo kratke odgovore, dok je 37 pitanja bilo zatvorenog tipa. Ukupan broj pitanja nižeg reda bio je 118. U sljedećim primjerima pitanja i odgovori zabilježeni su točno onako kako su ih nastavnici i učenici iznijeli.

Kao što je navedeno, 43 pitanja od ukupnog broja pitanja u osnovnim školama su provjerna pitanja. Navedeno je nekoliko primjera takvih pitanja:

- »Kako ovo čitamo, Livio?«

- What kind of questions are these with 'who'?"

- »What does it mean to take part? «

Nadalje, 38 od 55 pitanja zahtijevala su kratke odgovore, primjerice:

- Who is sad because of going to Africa? «

- »How does Luke feel?"

- »How do we call these? «(Nastavnica pokazuje papirus na slici) 
Naposljetku, 37 od 55 pitanja bila su pitanja zatvorenog tipa, primjerice:

- »How many pyramids are there in Gizah?«

- »How long did the Egyptian society last? «

- »Did you have any kind of cake?"

Unutar kategorije pitanja višeg reda utvrdilo se da je od ukupnog broja pitanja ( $\mathrm{N}=55) 12$ stvarnih pitanja, 18 pitanja zahtijevalo je dulje odgovore, dok je bilo 17 pitanja otvorenog tipa. Ukupan broj pitanja višeg reda bio je 47.

Kao što je prije navedeno, od ukupno 55 pitanja koja postavljaju nastavnici u osnovnim školama stvarnih je bilo 12 . U nastavku su navedeni primjeri:

- »Do you find explorers interesting?«

- »How many of you like geography? «

- »Would you like to have this kind of party? «

Nadalje, 17 od 55 pitanja bila su pitanja koja zahtijevaju dulje odgovore:

- »What do you see in this photo?"

- »What was the life in Egypt?«

- »How did they preserve the body of the dead people? «

Naposljetku, 18 od 55 pitanja bila su pitanja otvorenog tipa:

- »Adrian, have you got anything to add?"

- »Ivan, do you remember any birthday party?«

- »What was the life in Egypt?«

Prema predstavljenim rezultatima utvrđeno je da su u osnovnim školama najčešće postavljana provjerna pitanja $(\mathrm{N}=43)$, pitanja koja zahtijevaju kratke odgovore te pitanja zatvorenog tipa. Pitanja višeg reda su prisutna, ali ne toliko učestalo kao pitanja nižeg reda, a uključuju stvarna pitanja $(\mathrm{N}=12)$, pitanja koja zahtijevaju dulje odgovore $(\mathrm{N}=18)$ te pitanja otvorenog tipa $(\mathrm{N}=17)$, a ukupan broj pitanja višeg reda je 47. Ukratko, došlo se do rezultata da su $72 \%$ pitanja koja nastavnici postavljaju u osnovnim školama pitanja nižeg reda, dok je pitanja višeg reda svega $28 \%$. Rezultati su prikazani na Grafikonu 2. 
Grafikon 2. Osnovne škole: Pitanja nižeg i pitanja višeg reda

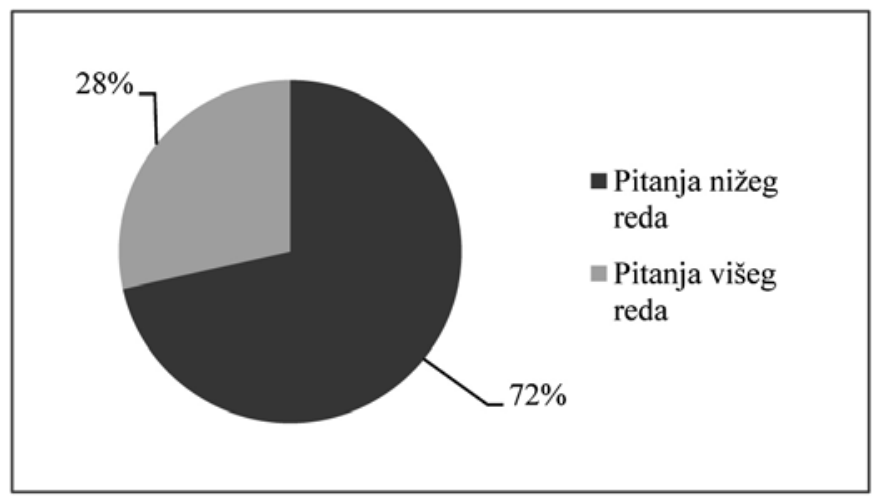

\subsection{Rezultati analize setova pitanja $i$ odgovora u osnovnim školama}

Iz raznolikih pitanja proizlaze i raznoliki odgovori, a na temelju vrste pitanja može se očekivati manje ili više kompleksan odgovor. U ovom istraživanju jedan od ciljeva bio je odrediti postoji li veza između vrste pitanja i kompleksnosti odgovora. Na temelju analize svakog seta pitanja i odgovora čini se da se setovi pitanja i odgovora u osnovnim školama uglavnom sastoje od provjernih pitanja, pitanja koja zahtijevaju kratke odgovore i pitanja zatvorenog tipa, a koja zahtijevaju mišljenje nižeg reda iz čega proizlaze manje kompleksni odgovori te ujedno predstavljaju manji izazov učenicima. U nastavku su primjeri odgovora učenika:

S. 1. T: »Who is angry? «

$\mathrm{S}: »$ Luke is angry. «

S. 2. T: »And what else? «

$\mathrm{S}: » H e$ 's thirsty.»

S druge strane, iz setova pitanja i odgovora koji su uglavnom uključivali stvarna pitanja, pitanja koja zahtijevaju dulje odgovore i pitanja otvorenog tipa, a koja zahtijevaju mišljenje višeg reda proizlaze i kompleksniji odgovori te predstavljaju veći izazov učenicima. Primjeri iz ove skupine setova prikazani su u nastavku: 
S. 7. T: »OK. What do you know about him?"

$\mathrm{S} 3$ : »Ra ruled in the sky and Seth ruled in the underworld.«

$\mathrm{T}: » N i c e . »$

S. 9. T: »Who can tell me something about the next explorer? «

S1: »His name was Marco Polo. He is famous for his journeys to China and other places.«

Tablica 1. Setovi pitanja i odgovora u osnovnim školama: Distribucija vrsta pitanja

\begin{tabular}{|c|c|c|c|c|c|c|c|c|c|c|c|c|}
\hline & \multicolumn{11}{|c|}{ Pitanja - manji izazov - veći izazov } \\
\hline & & $\begin{array}{c}1 . \\
\text { set }\end{array}$ & $\begin{array}{l}2 . \\
\text { set }\end{array}$ & $\begin{array}{l}3 . \\
\text { set }\end{array}$ & $\begin{array}{l}4 . \\
\text { set }\end{array}$ & $\begin{array}{l}5 . \\
\text { set }\end{array}$ & $\begin{array}{l}6 . \\
\text { set }\end{array}$ & $\begin{array}{c}7 . \\
\text { set }\end{array}$ & $\begin{array}{c}8 . \\
\text { set }\end{array}$ & $\begin{array}{l}9 . \\
\text { set }\end{array}$ & $\begin{array}{l}10 . \\
\text { set }\end{array}$ & $\begin{array}{l}11 . \\
\text { set }\end{array}$ \\
\hline \multirow{3}{*}{ 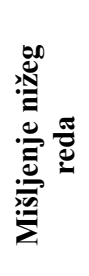 } & $\begin{array}{l}\text { Provjerna } \\
\text { pitanja }\end{array}$ & $*$ & $*$ & $*$ & $*$ & $*$ & & & & & $*$ & \\
\hline & $\begin{array}{c}\text { Pitanja zatvorenog } \\
\text { tipa }\end{array}$ & $*$ & $*$ & $*$ & $*$ & * & & & & & * & \\
\hline & $\begin{array}{c}\text { Pitanja s kratkim } \\
\text { odgovorima }\end{array}$ & $*$ & $*$ & $*$ & & & * & & & & & * \\
\hline \multirow{3}{*}{ 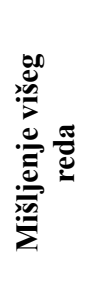 } & $\begin{array}{l}\text { Stvarna } \\
\text { pitanja }\end{array}$ & & & & & & $*$ & $*$ & $*$ & * & & $*$ \\
\hline & $\begin{array}{c}\text { Pitanja otvorenog } \\
\text { tipa }\end{array}$ & & & & & & $*$ & $*$ & $*$ & $*$ & & * \\
\hline & $\begin{array}{l}\text { Pitanja s duljim } \\
\text { odgovorima }\end{array}$ & & & & $*$ & $*$ & & * & * & $*$ & $*$ & \\
\hline
\end{tabular}

\subsection{Rezultati analize pitanja u srednjim školama}

Prvi cilj bio je utvrditi koje vrste pitanja koriste nastavnici u srednjim školama. Na temelju analize 52 pitanja utvrđeno je da nastavnici u srednjim školama koriste različite vrste pitanja. Unutar kategorije autentičnosti u komunikaciji došlo se do rezultata da su postavljena ukupno 24 (46\%) stvarna pitanja te 28 (54\%) provjernih pitanja. Nadalje, postavljeno je i 27 (52\%) pitanja koja zahtijevaju kratke odgovore te 25 
(48\%) pitanja koja zahtijevaju dulje odgovore. Ukupno je postavljeno 29 (56 \%) pitanja zatvorenog tipa te 23 (44\%) pitanja otvorenog tipa. Rezultati su prikazani u Grafikonu 3.

Grafikon 3. Vrste pitanja koja se koriste u srednjim školama

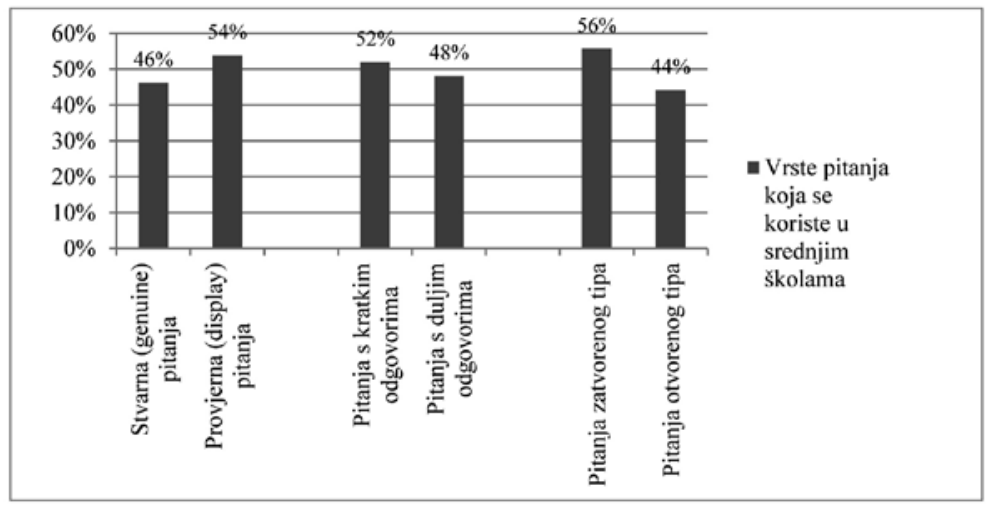

Kako bi se utvrdilo koje vrste pitanja se najčešće postavljaju, pitanja su kategorizirana kao pitanja nižeg reda i pitanja višeg reda. Kao što je već navedeno, pitanja nižeg reda uključuju provjerna pitanja, pitanja koja zahtijevaju kratke odgovore te pitanja zatvorenog tipa, dok pitanja višeg reda uključuju stvarna pitanja, pitanja koja zahtijevaju dulje odgovore te pitanja otvorenog tipa. Unutar kategorije pitanja nižeg reda 28 je provjernih pitanja, 29 je pitanja zatvorenog tipa, dok je 27 pitanja koja zahtijevaju kratke odgovore. Ukupan broj pitanja nižeg reda bio je 84 .

U nastavku su primjeri pitanja unutar pojedine kategorije.

Primjeri provjernih pitanja:

- »Can you complete noun+preposition combinations, you remember this? «

- „Can you name few prepositions? «

- »What are adverbs?«

Primjeri pitanja koja zahtijevaju kratke odgovore:

- „Can you give me a synonym or a translation? «

- »What is past participle of 'bring'?"

- »This paragraph is about which sport?« 
Primjeri pitanja zatvorenog tipa:

- »Is Magdalena's sentence correct?«

- »What type of text is text number 1?«

- »What does recruit mean?"

Unutar kategorije pitanja višeg reda 24 su stvarna pitanja, 23 su pitanja otvorenog tipa, a 25 pitanja zahtijevalo je dulje odgovore. Ukupan broj pitanja višeg reda je 72. U nastavku su primjeri pitanja višeg reda u srednjim školama podijeljeni u prije spomenute skupine.

Primjeri stvarnih pitanja:

- »What does love at first sight mean?"

- »Can you fall in love with somebody without meeting them face to face? «

- »Do you believe everything you see on the Internet?"

Primjeri pitanja koja zahtijevaju dulje odgovore:

- »In what ways can online relationships be dangerous? «

- »Why do you like it?"

- »Roko, why are you against online dating?«

Primjeri pitanja otvorenog tipa:

- »Do you agree with this quotation 'The ball is man's most disastrous invention'?"

- »Do you use technology? «

- »Do you agree with your colleague's opinion on Pharmopho$n e ? \ll$

Došlo se do zaključka da se u srednjim školama najčešće koriste provjerna pitanja $(\mathrm{N}=28)$, pitanja zatvorenog tipa $(\mathrm{N}=29)$ te pitanja koja zahtijevaju kratke odgovore ( $\mathrm{N}=27$ ), što je ukupno 72 pitanja. Ukratko, rezultati su pokazali da je $54 \%$ pitanja koja se postavljaju u srednjim školama nižeg reda, u usporedbi s pitanjima višeg reda kojih je $46 \%$. Rezultati su prikazani u Grafikonu 4. 
Grafikon 4. Srednje škole: Pitanja nižeg i pitanja višeg reda

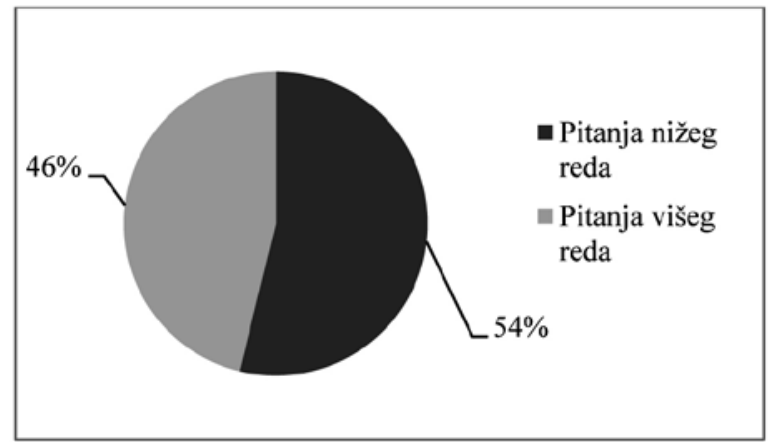

\subsection{Rezultati analize setova pitanja $i$ odgovora u srednjim školama}

Jedan od ciljeva ovog istraživanja također je bio utvrditi vezu između vrsta pitanja i kompleksnosti odgovora. Na temelju analize pojedinog seta pitanja i odgovora utvrđeno je da su setovi u srednjim školama, koji uglavnom uključuju provjerna pitanja, pitanja koja zahtijevaju kratke odgovore i pitanja zatvorenog tipa, a zahtijevaju mišljenje nižeg reda, rezultirali manje kompleksnim odgovorima te su predstavljali manji izazov učenicima. Primjeri odgovora učenika za ovu skupinu su:

S. 1. T: »What kind of magazine is the article from? «

$\mathrm{S} 1:$ »Science magazine.«

S. 2. $\mathrm{T}: »$ What year is it from? «

$\mathrm{S} 2:$ » 2018«

S druge strane, setovi pitanja i odgovora koji su uključivali stvarna pitanja, pitanja koja zahtijevaju dulje odgovore te pitanja otvorenog tipa, a zahtijevaju mišljenje višeg reda rezultirali su kompleksnijim odgovorima te su predstavljali veći izazov učenicima. Primjeri odgovora za ovu skupinu su sljedeći:

S. 9. T: »How important is fashion to you?»

S: »I don 't think it's very important. It's just clothes and

I don't think about it. I just wear what I like.«

S. 11. T: »Do you know anyone who is addicted to gambling? « 
S 5: »I had a friend who was addicted and he had a lot of problems with his parents and friends. He always wanted to borrow money from us.《

Rezultati analize setova pitanja i odgovora u srednjim školama prikazani su u Tablici 2.

Tablica 2. Setovi pitanja i odgovora u srednjim školama: Distribucija vrsta pitanja

\begin{tabular}{|c|c|c|c|c|c|c|c|c|c|c|c|c|}
\hline & \multicolumn{11}{|c|}{ Pitanja - manji izazov - veći izazov } \\
\hline & & $\begin{array}{l}1 . \\
\text { set }\end{array}$ & $\begin{array}{l}2 . \\
\text { set }\end{array}$ & $\begin{array}{l}3 . \\
\text { set }\end{array}$ & $\begin{array}{l}4 . \\
\text { set }\end{array}$ & $\begin{array}{l}5 . \\
\text { set }\end{array}$ & $\begin{array}{c}6 . \\
\text { set }\end{array}$ & $\begin{array}{l}7 . \\
\text { set }\end{array}$ & $\begin{array}{l}8 . \\
\text { set }\end{array}$ & $\begin{array}{l}9 . \\
\text { set }\end{array}$ & $\begin{array}{l}10 . \\
\text { set }\end{array}$ & $\begin{array}{l}11 . \\
\text { set }\end{array}$ \\
\hline \multirow{3}{*}{ 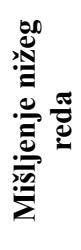 } & Provjerna pitanja & $*$ & $*$ & $*$ & $*$ & & $*$ & & & & & \\
\hline & $\begin{array}{c}\text { Pitanja zatvorenog } \\
\text { tipa }\end{array}$ & $*$ & $*$ & $*$ & $*$ & & $*$ & & & & & \\
\hline & $\begin{array}{c}\text { Pitanja s kratkim } \\
\text { odgovorima }\end{array}$ & $*$ & $*$ & $*$ & & & & & & & & \\
\hline \multirow{3}{*}{ 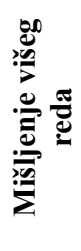 } & Stvarna pitanja & & & & & $*$ & & $*$ & $*$ & * & $*$ & $*$ \\
\hline & $\begin{array}{c}\text { Pitanja otvorenog } \\
\text { tipa }\end{array}$ & & & & & $*$ & & $*$ & $*$ & $*$ & $*$ & $*$ \\
\hline & $\begin{array}{l}\text { Pitanja s duljim } \\
\text { odgovorima }\end{array}$ & & & & $*$ & $*$ & $*$ & $*$ & * & $*$ & $*$ & * \\
\hline
\end{tabular}

\subsection{Rezultati analize svrhe postavljanja pitanja u osnovnim i srednjim školama}

Sljedeći dio istraživanja obuhvaćao je svrhe postavljanja pitanja. Kao što je prije opisano, postoje različite svrhe postavljanja pitanja. Na temelju analize pitanja u osnovnim i srednjim školama može se primijetiti nekoliko svrha, a koje ujedno odgovaraju svrhama koje je navela Ur (2012). Rezultati su prikazani u Tablici 3. 
Tablica 3. Svrhe postavljanja pitanja u osnovnim i srednjim školama

\begin{tabular}{|c|c|c|}
\hline $\begin{array}{l}\text { Svrhe postavljanja } \\
\text { pitanja }\end{array}$ & Osnovne škole & Srednje škole \\
\hline $\begin{array}{l}\text { Kako bi se pružio } \\
\text { model govora ili } \\
\text { razmišljanja }\end{array}$ & & $\begin{array}{l}\text { »Can anyone give an example of } \\
\text { phrasal verb, use it in a sentence? « } \\
\text { »Is Magdalena's sentence } \\
\text { correct? « } \\
\text { »Šme, what would you change in } \\
\text { Magdalena's sentence? « }\end{array}$ \\
\hline $\begin{array}{c}\text { Kako bi se nešto } \\
\text { doznalo od učenika }\end{array}$ & $\begin{array}{l}\text { »What do you know about Ancient } \\
\text { Egypt? « } \\
\text { »How many of you like } \\
\text { Geography? « } \\
\text { »Can you name some of the } \\
\text { symbols from the picture? « }\end{array}$ & $\begin{array}{l}\text { "Is love at first sight possible? " } \\
\text { "Roko, why are you against online } \\
\text { dating? « } \\
\text { "Are there any words you don't } \\
\text { understand? « }\end{array}$ \\
\hline $\begin{array}{l}\text { Kako bi se } \\
\text { provjerilo ili ispitalo } \\
\text { razumijevanje, } \\
\text { znanje ili vještina }\end{array}$ & $\begin{array}{l}\text { »hat does it mean to take part» } \\
\text { »How would you translate the } \\
\text { word convinced into Croatian? « } \\
\text { "What kind of questions are these } \\
\text { with 'who'?" }\end{array}$ & $\begin{array}{l}\text { »Can anyone explain the proverb } \\
\text { from the introduction? « } \\
\text { »What are adverbs? « } \\
\text { "What is the object in this } \\
\text { sentence? « }\end{array}$ \\
\hline $\begin{array}{c}\text { Kako bi se učenike } \\
\text { naviklo na aktivno } \\
\text { učenje }\end{array}$ & $\begin{array}{l}\text { "What do you know about Ancient } \\
\text { Egypt? « } \\
\text { »Do you know any other god? « } \\
\text { »Adrian, have you got anything } \\
\text { to add?« }\end{array}$ & $\begin{array}{l}\text { "Can you complete } \\
\text { noun + preposition combinations, } \\
\text { you remember this? « } \\
\text { "Do you agree with this quotation } \\
\text { 'The ball is man's most disastrous } \\
\text { invention'? " } \\
\text { "Can you tell me something } \\
\text { about the word order in English } \\
\text { language?" }\end{array}$ \\
\hline $\begin{array}{l}\text { Kako bi se usmjerila } \\
\text { pažnja ili napravio } \\
\text { uvod u temu koja će } \\
\text { se proučavati }\end{array}$ & $\begin{array}{l}\text { »Do you find explorers intere- } \\
\text { sting? « } \\
\text { »Ivan, do you remember any } \\
\text { birthday parties? « } \\
\text { »Do you know anything about F. } \\
\text { Magellan?« }\end{array}$ & $\begin{array}{l}\text { »hat does love at first sight } \\
\text { mean?" } \\
\text { »In what ways can online } \\
\text { relationships be dangerous? « } \\
\text { »What can you see in the picture? « }\end{array}$ \\
\hline $\begin{array}{l}\text { Kako bi se } \\
\text { informiralo razred } \\
\text { kroz odgovore } \\
\text { učenika, a ne kroz } \\
\text { podražaj nastavnika }\end{array}$ & & $\begin{array}{l}\text { "Can you explain these adverbs } \\
\text { - supposedly, largely, onwards, } \\
\text { thus, loosely, ironically, resolutely, } \\
\text { widely? « } \\
\text { »Can you tell me something } \\
\text { about the word order in English } \\
\text { language? " } \\
\text { "Šime, what would you change in } \\
\text { Magdalena's sentence? « }\end{array}$ \\
\hline
\end{tabular}




\begin{tabular}{|c|c|c|}
\hline $\begin{array}{c}\text { Svrhe postavljanja } \\
\text { pitanja }\end{array}$ & Osnovne škole & Srednje škole \\
\hline $\begin{array}{l}\text { Kako bi se slabijim } \\
\text { učenicima pružila } \\
\text { prilika za } \\
\text { sudjelovanjem }\end{array}$ & $\begin{array}{l}\text { »Would you like to have this kind } \\
\text { of party?« } \\
\text { »How are you today, Duje?« } \\
\text { »How does Luke feel? « }\end{array}$ & $\begin{array}{l}» \text { What is the title of the article? } " \\
» T h i s \text { paragraph is about which } \\
\text { sport?« }\end{array}$ \\
\hline $\begin{array}{l}\text { Kako bi se } \\
\text { potaknulo } \\
\text { razmišljanje }\end{array}$ & $\begin{array}{l}\text { »How would you translate the } \\
\text { word convinced into Croatian? « } \\
\text { »How do people remember the } \\
\text { Egyptians?« }\end{array}$ & $\begin{array}{l}\text { »n what ways can online } \\
\text { relationships be dangerous?« } \\
\text { »What are the advantages or } \\
\text { disadvantages of online dating? « } \\
\text { Do you agree with your } \\
\text { colleague's opinion on } \\
\text { Pharmophone?« }\end{array}$ \\
\hline $\begin{array}{l}\text { Kako bi se učenici } \\
\text { osobno povezali s } \\
\text { problemom }\end{array}$ & $\begin{array}{l}\text { »Do you find explorers } \\
\text { interesting? « } \\
\text { »Would you like to have this kind } \\
\text { of party? « } \\
\text { »How are you today, Duje?» }\end{array}$ & $\begin{array}{l}\text { »Do you like the song we've just } \\
\text { listened to?" } \\
\text { »Do you believe everything you see } \\
\text { on the Internet? « } \\
\text { "Are you satisfied with your } \\
\text { homework? « }\end{array}$ \\
\hline $\begin{array}{c}\text { Kako bi se } \\
\text { potaknulo } \\
\text { samoizražavanje }\end{array}$ & & $\begin{array}{l}\text { »Do you agree with your } \\
\text { colleague's opinion on } \\
\text { Pharmophone? « } \\
\text { »Do you use technology? « } \\
\text { "Were you successful with the } \\
\text { exercise? « }\end{array}$ \\
\hline
\end{tabular}

\subsection{Usporedba rezultata u osnovnim i srednjim školama}

Analiza pojedinačnih pitanja i setova pitanja i odgovora u osnovnim i srednjim školama pokazuje određene rezultate koji bi mogli poslužiti kao temelj za rješavanje problema u nastavi u području interakcije u nastavi. Može se reći da nastavnici u osnovnim i srednjim školama koriste iste vrste pitanja koje uključuju stvarna i provjerna pitanja, pitanja otvorenog i zatvorenog tipa, kao i pitanja koja zahtijevaju kratke i duge odgovore. Međutim, postoji razlika u učestalosti korištenja određenih vrsta pitanja. Primjerice, u osnovnim školama veća je učestalost korištenja pitanja nižeg reda (72 \%) u usporedbi s pitanjima višeg reda (28\%). S druge strane, u srednjim školama $54 \%$ pitanja bila su pitanja nižeg reda u usporedbi s $46 \%$ pitanja višeg reda. Rezultati su prikazani u Grafikonu 5. 
Grafikon 5. Usporedba pitanja u osnovnim i srednjim školama

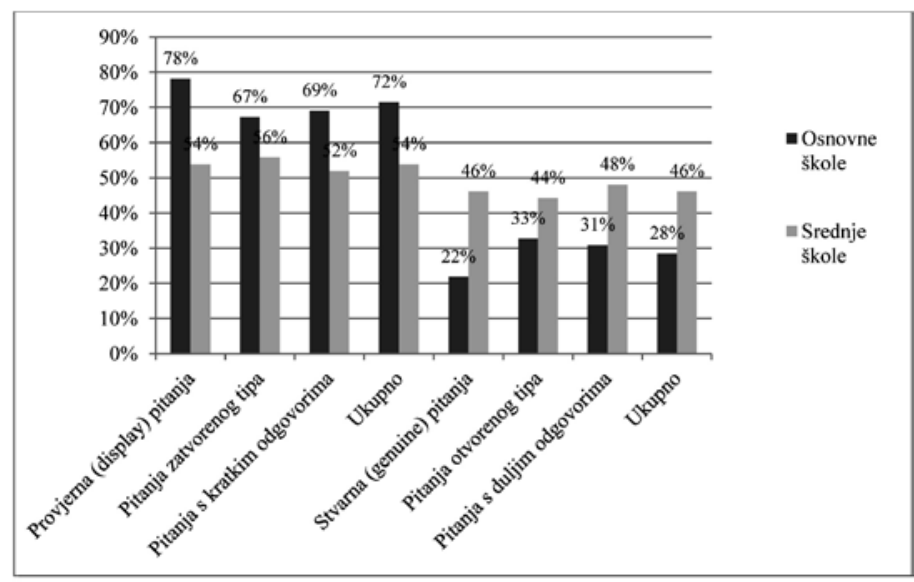

Analizom setova pitanja i odgovora rezultati otkrivaju da što su pitanja i odgovori kompleksniji u svakom setu veća je učestalost pitanja višeg reda; drugim riječima, što su pitanja i odgovori kompleksniji, veća je učestalost stvarnih pitanja, pitanja koja zahtijevaju dulje odgovore te pitanja otvorenog tipa. Stoga se može zaključiti da i u osnovnim i u srednjim školama kompleksnost odgovora ovisi o vrsti pitanja koju nastavnik postavi. Daljnjom analizom pitanja prikazano je da postoje različite svrhe postavljanja pitanja. Nastavnici su uglavnom pokušali pružiti model govora i razmišljanja, saznati nešto od učeni$\mathrm{ka}$, provjeriti ili ispitati razumijevanje, znanje ili vještinu, potaknuti učenike na aktivno učenje, usmjeriti pažnju ili napraviti uvod u temu koja se proučavala, informirati učenike kroz odgovore drugih učenika, a ne kroz podražaj nastavnika, pružiti slabijim učenicima priliku za sudjelovanjem, stimulirati razmišljanje, potaknuti učenike na osobno povezivanje s problemom te su pokušali potaknuti samoizražavanje. Svrhe postavljanja pitanja vrlo su slične u osnovnim i srednjim školama, međutim u srednjim školama više je pitanja koja su bila model govoru i razmišljanju, koja su stimulirala razmišljanje i poticala samoizražavanje, što ne iznenađuje jer su u srednjim školama pitanja višeg reda učestalija. 


\section{Rasprava}

Interakcija u razredu bogat je izvor informacija o praksi u nastavi. Deskriptivna analiza je pokazala da su nastavnici stranog jezika pretežito koristili pitanja nižeg reda, poput onih zatvorenog tipa, čiji je cilj bio provjeriti znanje. Ta se pitanja razlikuju od onih višeg reda, primjerice otvorenog tipa, koja učenike potiču na kritičko razmišljanje. Nastavnici u srednjim školama više su koristili stvarna pitanja, ali su provjerna bila dominantna. Ovi rezultati u skladu su s drugim sličnim istraživanjima koja su također pokazala veću upotrebu provjernih pitanja u odnosu na uporabu stvarnih (referentnih) pitanja u učionicama stranih jezika (Lee, 2006; Long i Sato, 1984; McNeil, 2012). Ur (2012) predlaže češću upotrebu autentičnih pitanja kako bi se potakla »stvarna« komunikacija. Hattie (2008) tvrdi da postavljanjem pitanja nižeg reda učenike potičemo na pružanje odgovora nižeg reda. Naposljetku, istraživanja koja su proveli Lee (2006) i McNeil (2012) pokazala su da su provjerna pitanja vrlo važan dio pedagogije učenja stranog jezika.

Unatoč saznanjima novijih istraživanja (Lee, 2006; McNeil, 2012), rezultati ovog istraživanja pokazali su da uporaba stvarnih pitanja u osnovnim i srednjim školama potiče učenike na pružanje duljih i složenijih odgovora. Brock (1986) je u svom istraživanju inojezičnih učenika više razine otkrila da su nastavnici poticali učenike na pružanje duljih i složenijih odgovora uporabom referentnih pitanja. Čurković Kalebić (1993) svojim je istraživanjem došla do uvida da hrvatski učitelji učestalo postavljaju pitanja zatvorenog tipa što je u konačnici dovelo do pružanja jednostavnijih odgovora učenika. Štoviše, Wright (2016) tvrdi da da referentna pitanja mogu pospješiti jezični iznos učenika, njihovo pregovaranje o značenju poruke, kao i sam proces usvajanja inog jezika.

Nadalje, nastavnici u osnovnim školama pretežito su postavljali pitanja kako bi provjerili ili ispitali razumijevanje učenika, kako bi od njih nešto saznali (npr. činjenice), kako bi im usmjerili pažnju prilikom uvođenja nove teme ili kako bi slabije učenike uključili u raspravu. Rezultati prikupljeni u srednjim školama upućuju na slično stanje. Nastavnici su učenicima nerijetko postavljali pitanja nižeg tipa. No, važno je spomenuti da se u srednjim školama postavljao veći broj pitanja koja potiču samoizražavanje, koja potiču razmišljanje i pomoću kojih se učenici osobno mogu povezati s temom. Uzevši u obzir dob učenika, 
može se zaključiti da pitanja višeg reda odgovaraju zrelijim učenicima zbog njihove sposobnosti shvaćanja apstraktnih pojmova i više razine jezičnog umijeća (Brown i Lee, 2015). Ur (2012) smatra da bi pitanja višeg reda trebalo učestalo primjenjivati za vrijeme nastave. Pitanja višeg reda potiču učenike na komunikaciju koja nalikuje stvarnoj. To se očituje u razmjeni vjerodostojnih informacija koja je isključivo naglašena u KP. Nadalje, pitanja višeg reda služe kao »odskočna daska« za razvoj kritičkog mišljenja (Good i Brophy, 2008; Harris, 2014; Hattie, 2008). Štoviše, Ur (2012) tvrdi da se pitanja višeg reda mogu prilagoditi različitim razinama, što obuhvaća učenike mlađe i starije dobi.

Brown i Keely $(2015,7)$ u svom radu raspravljaju o tome kako kritički pristupiti određenom problemu. U tu su svrhu osmislili nekoliko pitanja koja nastavnicima mogu pomoći pri osmišljanju pitanja višeg reda: »Jesam li se zapitao 'zašto' netko želi da to vjerujem? Jesam li pisao bilješke o potencijalnim problemima o tome što je rečeno? Jesam li procijenio to što je rečeno? Jesam li sam došao do zaključka o temi na temelju razumnosti toga što je izrečeno? « Pravilno oblikovanje pitanja višeg reda nastavnicima može biti problematično i upravo to može dovesti do izbjegavanje njihove uporabe (Ur, 2012).

\section{Zaključak}

KP potiče na sudjelovanje u stvarnoj komunikaciji koja se može ostvariti u interaktivnoj učionici. Pitanja nastavnika mogu se smatrati pokretačima komunikacije između učenika i nastavnika. Rezultati ovog istraživanja pokazali su da se pitanja nižeg reda češće koriste u nastavi u osnovnim i u srednjim školama. Veća je učestalost korištenja pitanja nižeg reda u osnovnim školama u usporedbi sa srednjim školama, što se može pripisati razlikama u dobi učenika. Naime, većina pitanja postavljenih u srednjim školama su provjerna pitanja. Nadalje, dok se pitanja u osnovnim školama postavljaju prvenstveno kako bi se nešto doznalo od učenika (činjenice) te kako bi se provjerilo razumijevanje (znanje, vještina), cilj pitanja u srednjim školama je, između ostalog, potaknuti razmišljanje te samoizražavanje.

Iako je uporaba provjernih pitanja važan dio procesa učenja jezika, rezultati ovog istraživanja pokazali su da postavljanje stvarnih pitanja dovodi do pružanja duljih i složenijih odgovora. Uporaba takvih pitanja omogućuje vjerodostojniju komunikaciju, odnosno veći jezični ostvaraj 
učenika koji može doprinijeti njihovom jezičnom umijeću. Rezultati ovog istraživanja pokazali su da bi hrvatski nastavnici stranih jezika češće trebali postavljati složenija pitanja kako bi učenike potaknuli na kritičko promišljanje. Ovakva je praksa istaknuta kao jedan od ciljeva nove kurikularne reforme. Hrvatska obrazovna praksa i dalje se temelji na postavljanju pitanja koja od učenika zahtijevaju pružanje činjenica. Ovakvo poučavanje u suprotnosti je s načelima predstojeće reforme koja učenika smješta u središte nastavnog procesa (Priprema, praćenje i evaluacija eksperimentalnog programa cjelovite kurikularne reforme, 2019).

Razvoj učenikove komunikacijske kompetencije jedan je od ishoda KP, no važno je spomenuti da proces učenja jezika uključuje i razvoj učenikovih općih kognitivnih vještina poput razmišljanja višeg reda koje se može potaknuti uporabom stvarnih pitanja. Wilhelm (2014) ističe važnost postavljanja stvarnih pitanja koja će učenike potaknuti na rješavanje postojećeg problema svojim znanjem i kreativnim pristupom. Uvidi dobiveni ovim istraživanjem upućuju na potrebu preispitivanja postojeće obrazovne prakse. Drugim riječima, hrvatski nastavnici stranih jezika trebaju razmotriti valjanost do sada korištenih tehnika postavljanja pitanja u razredu.

\section{Literatura}

Allwright, Dick i Bailey, Kathleen M. (1991), Focus on the Language Classroom, Cambridge: Cambridge University Press.

Bloom, Benjamin S. (1956), Taxonomy of Educational Objectives, Handbook I: Cognitive Domain, New York: Longman, Green and Co. Ltd.

Brock, Cynthia A. (1986), »The effects of referential questions on ESL classroom discourse «, TESOL Quarterly, 20(1), str. 47-59.

doi: https://doi.org/10.2307/3586388

Brown, Douglas H. (2007), Teaching by Principles: An Interactive Approach to Language Pedagogy, San Francisco: Longman.

Brown, Douglas H. i Lee, Heekyeong (2015), Teaching by Principles - An Interactive Approach to Language Pedogogy, White Plains, NY: Pearson Education, Inc.

Browne, Neil M. i Keeley, Stuart, M. (2015), Asking the Right Quesitons: A Guide to Critical Thinking, Upper Saddle River, NJ: Pearson. 
Chaudron, Craig (1988), Second Language Classrooms: Research on Teaching and Learning, Cambridge: Cambridge University Press. doi: https://doi.org/10.1017/CBO9781139524469

Clegg Jr., Ambrose, A. (1987), »Why questions?«, u: Wilen, William, W. (ur.), Questions, Questioning Techniques, and Effective Teaching, Washington, D.C.: National Education Association, str. 11-22.

Čurković Kalebić, Sanja (1993), »O pitanju kao poticaju na jezičnu produkciju u didaktičkoj sredini«, u: Andrijašević, Marin i Vrhovac, Yvonne (ur.), Trenutak sadašnjosti u učenju jezika, zbornik radova HDPL, Zagreb: Hrvatsko društvo za primijenjenu lingvistiku, str. 77-83.

Čurković Kalebić, Sanja (2013), »EFL classroom interaction: Learner questions and teacher answers«, u: Mihaljević Djigunović, Jelena i Medved Krajnović, Marta (ur.), UZRT 2012: Empirical Studies in English Applied Linguistics, Zagreb: FF Press, str. 201-210.

Gallagher, James J., i Aschner, Mary Jane (1963), „A preliminary report on analysis of classroom interaction«, Merrill-Palmer Quarterly of Behavior and Development, 9, str. 183-194.

Good, Thomas L. i Brophy Jere E. (2008), Looking in Classrooms, Boston: Pearson Education, Inc.

Guilford, Joy (1956), »The structure of intellect«, Psychological Bulletin, 53, str. 267-93. doi: https://doi.org/10.1037/h0040755

Harmer, Jeremy (2007), The Practice of English Language Teaching, London: Longman.

Harris, Bryan (2014), Creating a Classroom Culture that Supports the Common Core (Teacher Questioning Conversation Techniques, and Other Essential Skills), New York: Routledge.

Hattie, John A. C. (2009), Visible Learning: A Synthesis of over 800 Meta-Analyses Relating to Achievement, New York: Routledge. doi: https://doi.org/10.4324/9780203887332

Lee, Yo-An (2006), »Respecifying display questions: Interactional resources for language teaching«, TESOL Quarterly, 40(4), str. 691-713.

doi: https://doi.org/10.2307/40264304

Long, Michael H. (1996), »The role of the linguistic environment in second language acquisition«, u: Ritchie, William, C. i Bhatia, Tej, K. (ur.), Handbook of Second Language Acquisition, San Diego: Academic Press, str. 413-468. doi: https://doi.org/10.1016/B978-012589042-7/50015-3

Long, Michael H. i Sato, Charlene, J. (1983), »Classroom foreigner talk discourse: forms and functions of teachers«, u: Seliger, Herbert, W. i Long, Michael H. (ur.), Classroom Oriented Research in Second Languages, Rowley, MA: Newbury House, str. 268-285. 
Long, Michael H. i Sato, Charlene, J. (1984), »Methodological issues in interlanguage studies: An interactionist perspective «, u Davies, Alan, Criper, Clive i Howatt, Anthony P. R. (ur.), Interlanguage, Edinburgh: Edinburgh University Press.

Mackay, Alison i Gass, Susan, M. (2005), Second Language Research-Methodology and Design, Mahwah, New Jersey: Lawrence Erlbaum Associates, Inc.

McNeil, Levi (2012), »Using talk to scaffold referential questions for English language learners«, Teaching and Teacher Education, 28(3), str. 396-404. doi: https://doi.org/10.1016/j.tate.2011.11.005

Nunan, David i Bailey, Kathleen, M. (2009), Exploring Second Language Classroom Research, Boston: Heinle, Cengage Learning.

Priprema, praćenje i evaluacija eksperimentalnog programa cjelovite kurikularne reforme »Škola za život« (2019), Dostupno na: skolazazivot.hr/pripremapracenje-i-evaluacija-eksperimentalnog-programa-cjelovite-kurikularne-reforme-skola-za-zivot/

Sanders, Norris M. (1966), Classroom Questions: What Kinds?, New York: Harper and Row.

Saville-Troike, Muriel (2012), Introducing Second Language Acquisition, New York: Cambridge University Press. doi: https://doi.org/10.1017/CBO9780511888830

Sinclair, John M. i Coulthard, Malcolm (1975), Towards an Analysis of Discourse: The English Used by Teachers and Pupils, Oxford: OUP.

Swain, Merrill (1985), »Communicative competence: Some roles of comprehensible input and comprehensible output in its development«, u: Gass, Susan i Madden, Carolyn (ur.), Input in Second Language Acquisition, Rowley, MA: Newbury House, str. 235-253.

Swain, Merrill (1995), »Three functions of output in second language learning «, u: Cook, Guy i Seidlhofer, Barbara (ur.), Principle and Practice in Applied Linguistics: Studies in Honour of H. G. Widdowson, Oxford: Oxford University Press, str. 125-144.

Ur, Penny (2001), A Course in Language Teaching, Practice and Theory, Cambridge: Cambridge University Press.

Ur, Penny (2012), A Course in English Language Teaching, Cambridge: Cambridge University Press.

Vrhovac, Yvonne (2001), Govorna komunikacija i interakcija na satu stranoga jezika, Zagreb: Naklada Ljevak.

Wajnryb, Ruth (1992/2012), Classroom Observation Tasks: A Resource Book for Language Teachers and Trainers, New York: Cambridge University Press.

Walsh, Steve (2011), Exploring Classroom Discourse: Language in Action, New York: Routledge. doi: https://doi.org/10.4324/9780203827826 
Walsh, Jackie A. i Sattes, Elizabeth D. (2005), Quality Questioning: ResearchBased Practice to Engage Every Learner, Thousand Oaks, CA: Corwin Press AEL.

Wilhelm, Jeffrey D. (2014), »How essential questions promote creativity and deep learning«, Knowledge Quest, 42(5), str. 36-41.

Wright, Brenda, M. (2016), »Display and referential questions: Effects on student responses«, Nordic Journal of English Studies, 15(4), str. 160-189.

\section{TEACHER QUESTIONS IN EFL CLASSROOMS}

\section{Kristina Vuleta, Anna Martinović}

Teacher questions can help students in the learning process, as well as aid in the development of higher-order thinking skills. In language classrooms, teacher questions are a major way of initiating interaction. The general aim of this research was to investigate the types of questions used by language teachers in English as a foreign language (EFL) classrooms. The data collection method included classroom observations which is commonly used in second language classroom research. The results showed that in both elementary and high schools, there was greater frequency in the use of lower-order questions compared to higher-order questions, while more complex questions and answers sets yielded higher frequency of higher-order questions. Furthermore, the complexity of students' responses depended on the type of questions posed by the teacher. The analysis also showed that although there were more questions that stimulated thinking and encouraged self-expression in high schools than in elementary schools; nevertheless, the large number of lower-order questions suggests the need for greater use of high-order thinking questions.

Key words: teacher questions, English as a foreign language (EFL), display questions, genuine questions 